\title{
Low serum myeloperoxidase in autistic children with gastrointestinal disease
}

This article was published in the following Dove Press journal:

Clinical and Experimental Gastroenterology

II August 2009

Number of times this article has been viewed

\section{Anthony J Russo' \\ Arthur Krigsman ${ }^{2}$ \\ Bryan Jepson ${ }^{2}$ \\ Andy Wakefield ${ }^{2}$}

'Research Director, Health Research Institute/Pfeiffer Treatment Center, Warrenville, IL, USA; ${ }^{2}$ Thoughtful House Center for Children, Austin, TX, USA
Correspondence: Anthony J Russo Research Director, Health Research Institute/Pfeiffer Treatment Center, 4575 Weaver Parkway, Warrenville, Illinois 60555, USA

Tel +l $6305050300 \times 207$

$\mathrm{Fax}+\mathrm{I} 6308360667$

Email ajrusso@hriptc.org
Aim: To assess serum myeloperoxidase (MPO) levels in autistic children with severe gastrointestinal (GI) disease and to test the hypothesis that there is an association between serum MPO concentration and inflammatory GI disease, including antineutrophil cytoplasmic antibodies (ANCA), previously seen in a subgroup of autistic children.

Subjects and methods: Serum from 40 autistic children with chronic digestive disease (most with ileo-colonic lymphoid nodular hyperplasia (LNH) and inflammation of the colorectum, small bowel and/or stomach), and 48 controls (12 age-matched autistic children with no GI disease, 20 age-matched children without autism or GI disease, and 16 nonautistic individuals with no family history of autism) were tested using enzyme-linked immunosorbent assays designed to quantitate serum MPO levels. MPO serum concentration of autistic children with GI disease was compared to GI disease severity (including LNH and erythema) and presence of ANCA.

Results: We found that a significant number of autistic children with chronic digestive disease had low serum levels of MPO. However, there was no significant relationship between these levels and severity of GI disease, including the presence of ANCA.

Discussion: These results suggest a relationship between low MPO levels and GI disease seen in a subpopulation of autism spectrum disorders individuals. MPO concentration may therefore be a useful biomarker for GI disease in this group of autistic children.

Keywords: autism spectrum disorders, autism, myeloperoxidase, GI disease, oxidative stress

\section{Introduction}

Oxidants are thought to be key components of the neutrophil host defense system. Upon contact with a pathogen, particularly bacteria and fungi, neutrophils produce a respiratory burst characterized by intense uptake of oxygen. The resulting superoxide dismutates into hydrogen peroxide $\left(\mathrm{H}_{2} \mathrm{O}_{2}\right)$. The toxicity of $\mathrm{H}_{2} \mathrm{O}_{2}$ to microbe pathogens is greatly enhanced by the heme enzyme myeloperoxidase (MPO), found in the azurophilic granules of neutrophils, which uses $\mathrm{H}_{2} \mathrm{O}_{2}$ to convert chloride $\left(\mathrm{Cl}^{-}\right)$into hypochlorous acid ( $\mathrm{HOCl})$. Although the exact mechanism is not completely understood, MPO also kills by directly chlorinating phagocytosed bacteria. ${ }^{1}$

In addition to killing bacteria, the products of the MPO-hydrogen peroxide- $\mathrm{Cl}$ system are believed to play a role in killing fungi, parasites, protozoa, viruses, tumor cells, natural killer (NK) cells, red cells, and platelets, and they may be involved in terminating the respiratory burst, because individuals with MPO deficiency have a prolonged reaction. ${ }^{2}$

Other functions of MPO include tyrosyl radical production, generation of tyrosine peroxide, mediation of the adhesion of myeloid cells via b2-integrins, and oxidation of serum lipoproteins. ${ }^{2}$ 
Autistic spectrum disorder (ASD) is a neurodevelopmental syndrome with onset prior to the age of 36 months. Diagnostic criteria consist of impairments in socialization and communication plus repetitive and stereotypic behaviors. ${ }^{3}$ Traits strongly associated with autism include movement disorders and sensory dysfunctions. ${ }^{4}$ Although autism may be apparent soon after birth, many autistic children experience at least several months, up to a year or more in some cases, of normal development followed by regression, defined as loss of function or failure to progress. ${ }^{4-6}$

Children with ASD frequently have accompanying gastrointestinal (GI) symptoms ${ }^{7-9}$ and pathology, which includes inflammation of the GI tract. ${ }^{10-13}$ Many autistic children, particularly those with GI disease, have a higher propensity and related incidence of fungal infections. ${ }^{14,15}$

We previously reported that a significant number of autistic children with GI disease have antineutrophil cytoplasmic antibodies (ANCA; both antiproteinase 3 [antiPR3] and anti-MPO), and that there is a relationship between individuals with ANCA and severity of intestinal disease. ${ }^{16}$ We have also reported that a significant number of autistic children with chronic digestive disease have anti-PR3 ANCA, low serum alpha-1 antitrypsin (AAT), and high serum PR3, which correlate with high severity of GI disease, suggesting that high PR3 levels may be causing ANCA in autistic children with severe GI problems. ${ }^{17}$ Because of this, and the observation that a significant number of autistic children with GI disease have anti-MPO ANCA, we hypothesized that altered MPO levels might be associated with the production of ANCA to MPO.

The data presented here suggests that a significant number of autistic children with GI disease are MPO deficient, and, although no correlation was found between GI disease, ANCA, and MPO levels, this data suggests that MPO deficiency might be a biomarker for this subgroup of autistic children.

\section{Materials and methods}

\section{ELISA to measure serum MPO levels (Kit - I.C.L. Inc, Newberg, OR 97I32)}

All reagents and specimens were equilibrated to room temperature before the assay was performed. One hundred microliters of a 1:10 dilution of the patient samples, calibrators (15-1.875 $\mathrm{ng} / \mathrm{ml}$ of affinity purified MPO), negative control of serum diluent alone, were added to the appropriate microwells of a microculture plate (each well contained anti-MPO). Wells were incubated for 60 minutes ( $\pm 5 \mathrm{~min}$ ) at room temperature, then washed $4 \times$ with wash buffer. One hundred microliters of anti-human MPO conjugated with hydrogen peroxidase (HPO) was added to all microwells, incubated for 60 minutes $( \pm 5 \mathrm{~min}$ ) at room temperature, then washed $4 \times$ with wash buffer. One hundred microliters of HPO substrate was then added to each microwell. After approximately 30 minutes at room temperature, the wells were read at $450 \mathrm{~nm}$ with an enzyme-linked immunosorbent assay (ELISA) reader (BioRad Laboratories, Inc., Hercules, CA, USA).

\section{Subjects and scoring of severity of Gl disease}

Serum from autistic individuals with GI disease was obtained from the Thoughtful House, Austin, Texas. ${ }^{a}$ All 40 children in this study with ASD (median age 6 years; range 2-16 years; 34 male) having GI symptoms, were investigated by ileocolonoscopy. Esophagogastroduodenoscopy was performed on these patients, but only those with GI symptoms were part of this study.

A reproducible scoring system, similar to the Crohn's Disease Endoscopic Index of Severity (CDEIS) was developed and used to evaluate this unique type of observed enterocolitis.

Macroscopic and histologic features for both upper and lower GI tract (such as ulcerations, erosions, lymphoid nodular hyperplasia [LNH], and erythema) were each scored out of 3 : mild (1 point), moderate ( 2 points), or marked (3 points) for a total score out of 12. A point system was also developed for severity of LNH alone. Patients were scored according to mild (1 point), moderate (2 points), or marked (3 points) LNH in each area (upper and lower GI) for a maximum of 6 points. And finally, a point system was also developed for severity of erythema alone. Patients were scored according to mild (1 point), moderate (2 points), or marked ( 3 points) erythema in each area (upper and lower GI) for a maximum of 6 points.

\section{Controls}

Three control groups (total $\mathrm{n}=48$ ) were studied, including 12 age- (mean 68 months), gender-( $80 \%$ male), and diagnosis- (61\% regressive onset) matched autistic children with no GI disease; 20 age- (mean 71 months) and gender(75\% male) matched children without autism or GI disease; 16 nonautistic individuals with no family history of autism. Serum and medical history of age- and gender-matched

${ }^{a}$ The Thoughtful House Center for Children, founded in 2005 and located in Austin, Texas, is a collaboration between medical professionals and scientists seeking means to help children with autism spectrum disorders through a combination of medical care, education, and research. 
Typical assay: Serum MPO levels in autistic children with GI disease

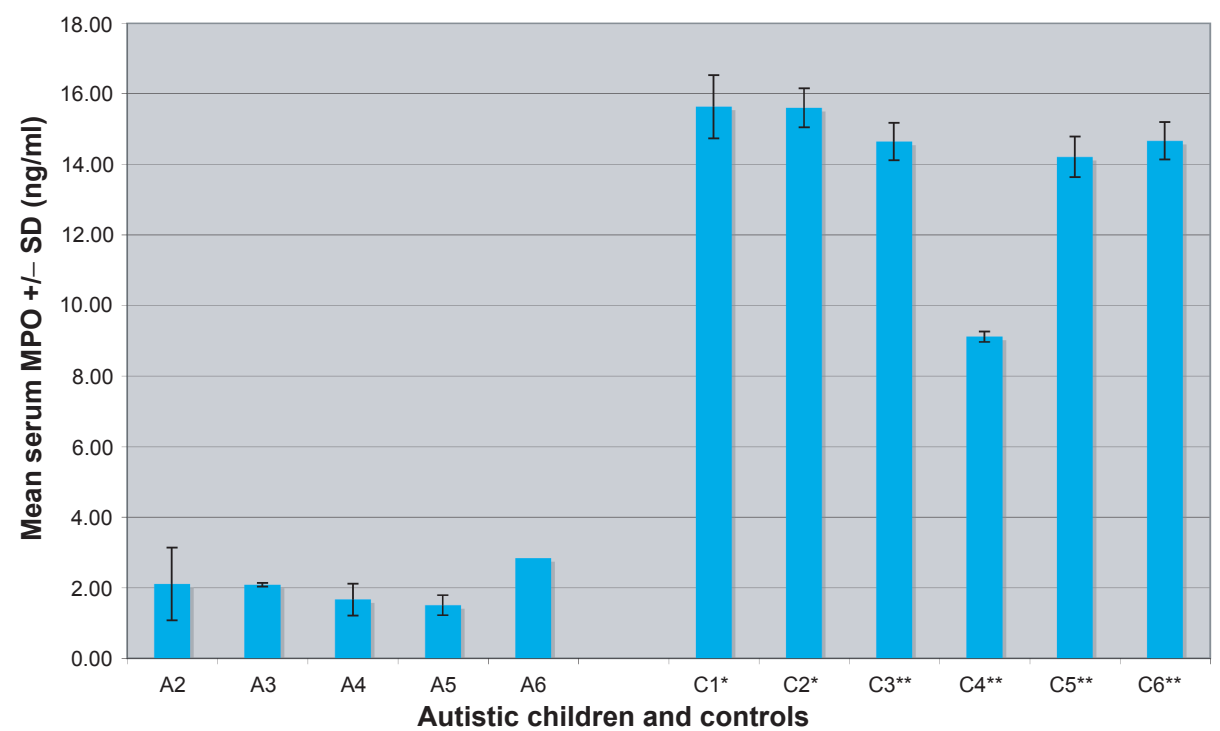

Figure I Serum MPO concentration was measured in a typical ELISA. Five autistic children (A) with GI disease, two autistic children with no GI disease controls (C*), and three nonautistic children with no Gl disease controls $\left(\mathbf{C}^{* *}\right)$ were tested. Four replicate samples were tested for each individual.

Abbreviations: ELISA, enzyme-linked immunosorbent assay; GI, gastrointestinal; MPO, myeloperoxidase.

controls were obtained from the Autism Genetic Resource Exchange (AGRE). ${ }^{\text {b }}$ Serum from nonautistic individuals with no family history of autism was obtained from National Disease Research Interchange. ${ }^{\circ}$

\section{Serums}

Experimental (Thoughtful House) and control (AGRE) serums were frozen at $-70{ }^{\circ} \mathrm{C}$ immediately after collection and cell/serum separation, then stored at $-70{ }^{\circ} \mathrm{C}$ until thawed for use in ELISAs.

\section{Statistics}

Inferential statistics were derived from analysis of variance (ANOVA), Student's $t$-test and odds ratios with 95\% confidence intervals.

\section{Results}

Using the ELISA described above, autistic children with chronic digestive disease were tested for serum MPO levels.

${ }^{b}$ The Autism Genetic Resource Exchange (AGRE) is the first collaborative gene bank for the study of autism spectrum disorders and one of the world's largest shared resources for the study of autism and related disorders, with a collection of over 900 well characterized multiplex and simplex families made available to the greater scientific community. Founded by Cure Autism Now (CAN) in 1997, AGRE is currently funded by the National Institute of Mental Health (NIMH) and Autism Speaks (AS), which merged with CAN in 2006.

'National Disease Research Interchange, Philadelphia, PA, USA.
Results of a typical assay are shown in Figure 1. In each assay, MPO concentrations were determined by comparing experimental and control serum levels with MPO standards and negative controls (sample diluent alone) (Figure 2). For each assay, there were three or four replicate samples tested in each group (control and experimental), and each assay was repeated at least twice. We found that the MPO concentration of autistic children with GI disease $(n=40$; $\mathrm{m}=2.45 \mathrm{ng} / \mathrm{ml} \pm 1.62$ ) was significantly lower than three control groups; age/diagnosis-matched autistic children with no GI disease $(\mathrm{n}=12 ; \mathrm{m}=14.35 \pm 5.87 ; \mathrm{p}<0.01)$; age/diagnosis-matched nonautistic children with no GI disease $(n=20 ; m=13.33 \pm 5.74 ; p<0.01)$ and individuals with no family history of autism $(\mathrm{n}=16 ; \mathrm{m}=10.55 \pm 5.71$; $\mathrm{p}<0.01$ ) (Figure 3).

Fifteen of the 40 autistic children with GI disease were categorized as having severe disease (score equal to or greater than 7 on total GI severity score criteria described above), six of 40 had severe LNH (score equal or greater than 4), and five of 40 had severe erythema (Table 1). Although most of the autistic children with GI disease had low MPO serum levels, there was no significant difference between MPO levels of these individuals and severity of GI disease, GI LNH $(p=0.4674)$ or erythema $(p=0.7806)$ (Table 3$)$. Although those individuals with severe GI disease did have higher MPO levels, the difference was still not significant $(\mathrm{p}=0.058)$. We also did not find a significant difference 


\section{Controls MPO ELISA}

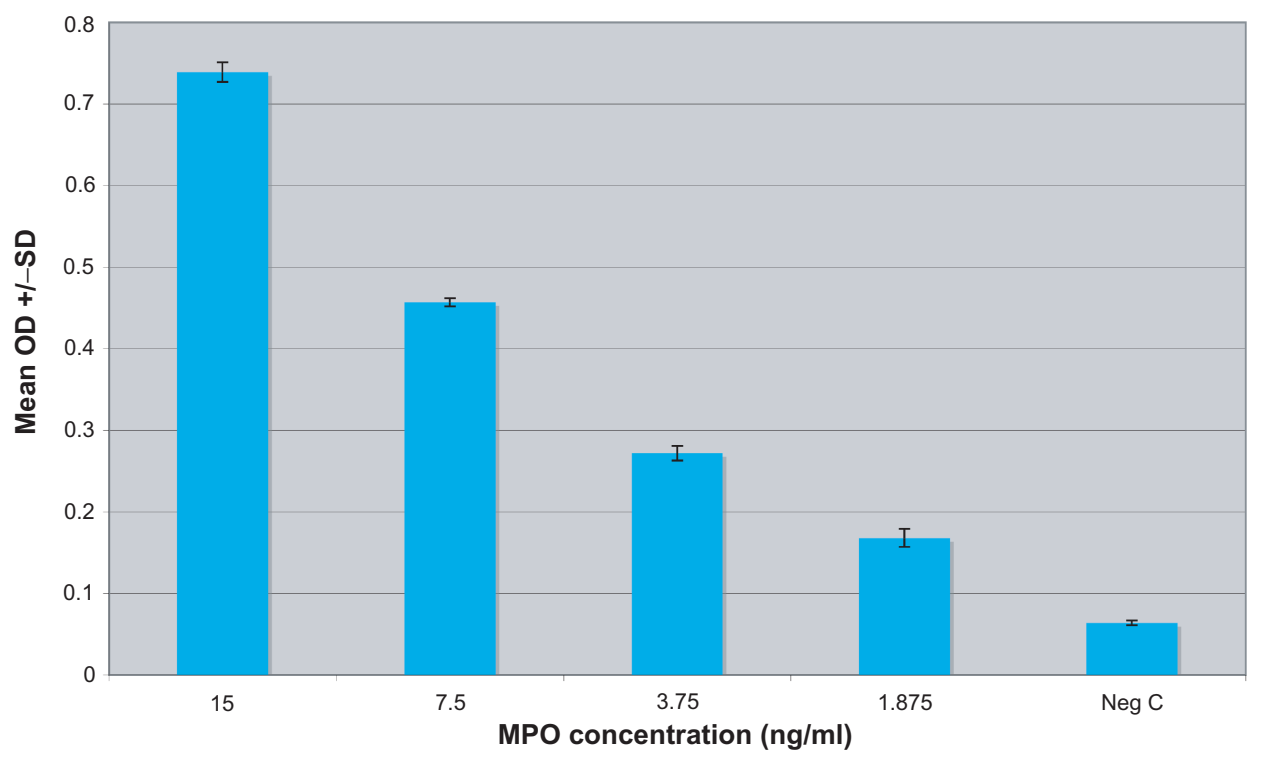

Figure 2 MPO serum concentration was established for each individual by testing and correlating to known standards of various concentrations of MPO (I5-I.875 ng/ml) as well as a negative control (serum diluent alone).

Abbreviation: MPO, myeloperoxidase.

between presence of ANCA and MPO serum concentration $(\mathrm{p}=0.3718)($ Table 2$)$.

\section{Discussion}

Our results show that autistic children with severe GI disease have low serum levels of MPO, and, although our data does not demonstrate a relationship between these low levels and type or level of severity of GI disease or the presence of ANCA, the data suggests that low serum MPO may be a biomarker for this subgroup of autistic children.

In addition to facilitating the destruction of pathogens, MPO may play a role in the etiology of atherosclerosis.

\section{Serum MPO levels in Autistic children with GI disease}

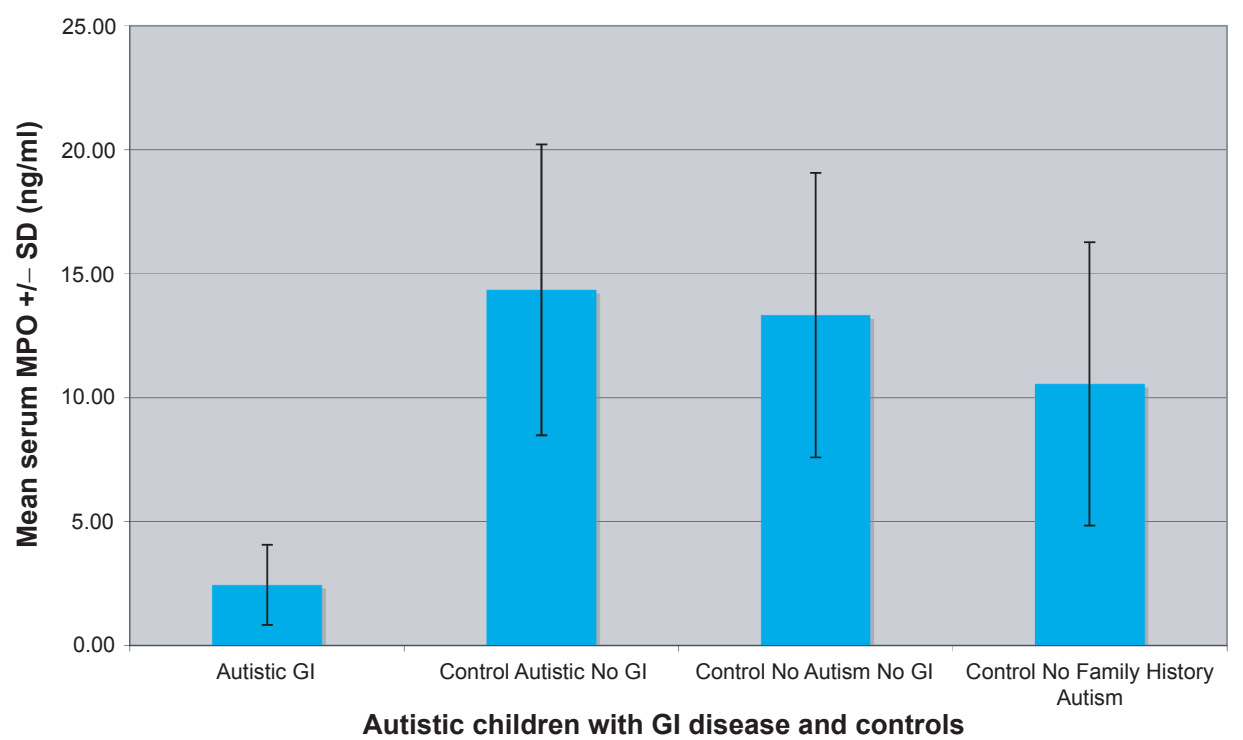

Figure 3 The mean \pm SD MPO concentration $(\mathrm{ng} / \mathrm{ml}$ ) of 40 autistic children with chronic digestive disease (most with ileo-colonic $\mathrm{LNH}$ and inflammation of the colorectum, small bowel and/or stomach) (autistic Gl), and 48 controls ( 12 age matched autistic children with no Gl disease; control autistic, no Gl), 20 age-matched siblings of autistic children, without autism or $\mathrm{Gl}$ disease (control, no autism, no $\mathrm{Gl}$ ), and 16 nonautistic individuals with no family history of autism (control no family history autism). Abbreviations: GI, gastrointestinal; LNH, lymphoid nodular hyperplasia; MPO, myeloperoxidase; SD, standard deviation. 


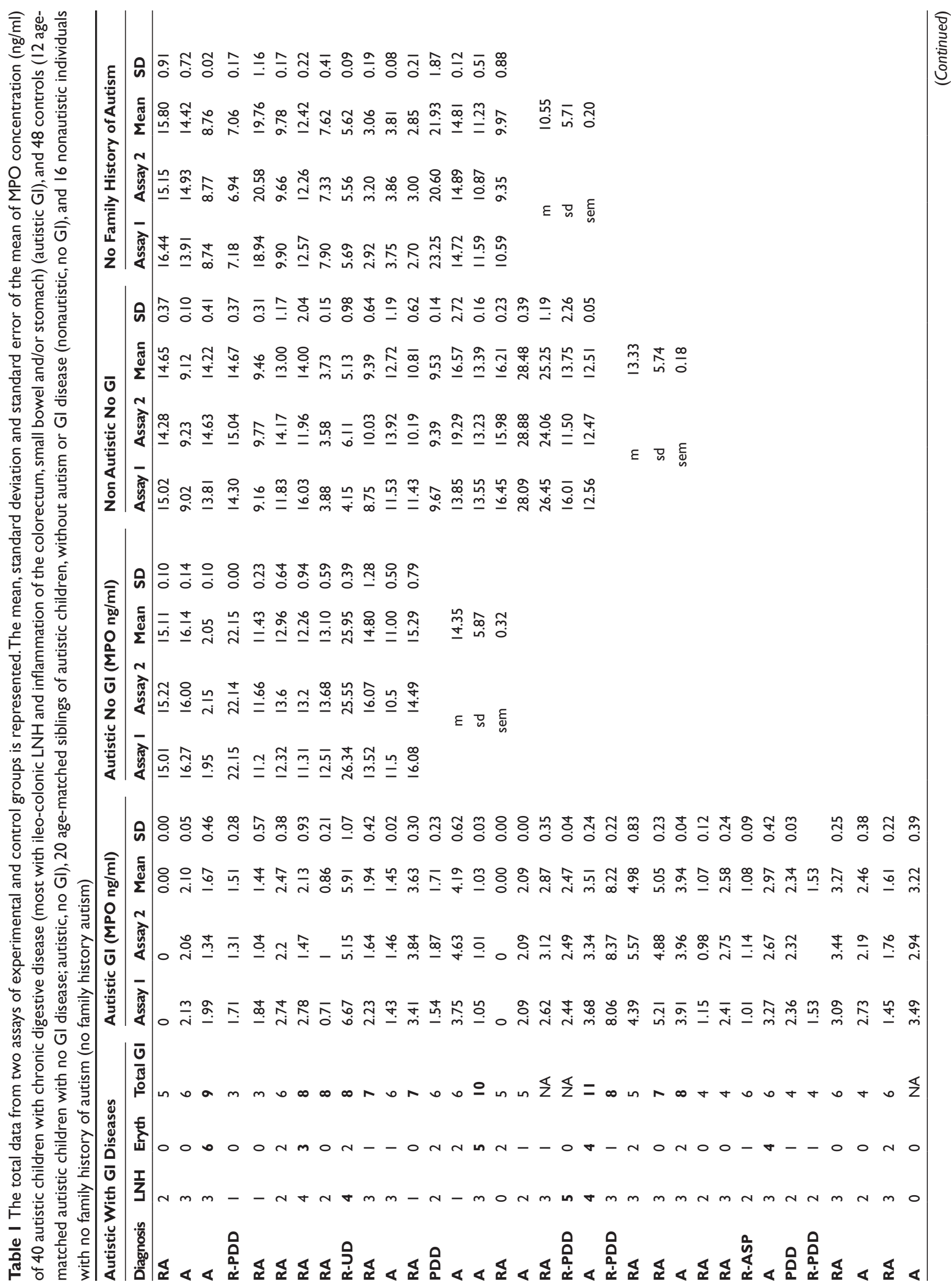




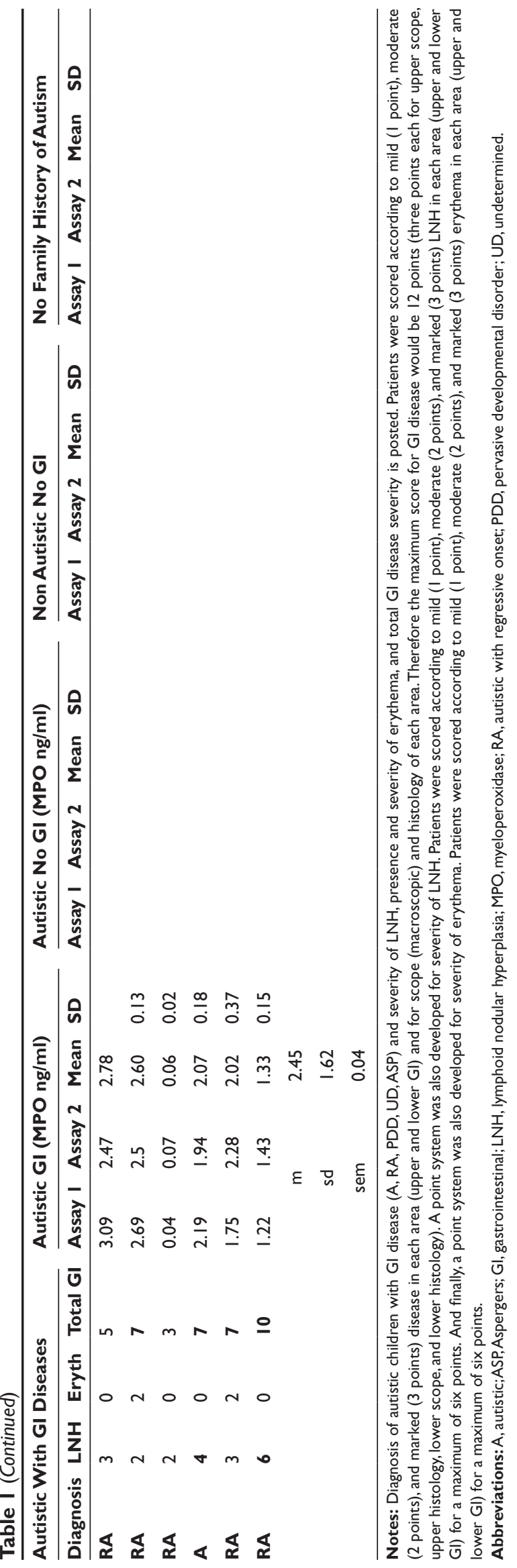

Researchers have demonstrated that patients with stable coronary artery disease have an increased cardiovascular risk if plasma MPO levels are elevated. ${ }^{18}$ These high MPO levels result in high oxidative stress associated with an increase in lipid peroxidation. There is evidence to suggest that MPO deficiency may protect against cardiovascular disease. ${ }^{19}$

MPO-deficient neutrophils produce superoxide and $\mathrm{H}_{2} \mathrm{O}_{2}$ properly, but are unable to convert $\mathrm{H}_{2} \mathrm{O}_{2}$ to $\mathrm{HOCl}$. As a consequence, neutrophil killing of some organisms is diminished early, but is normal late, as demonstrated by killing assays. ${ }^{20}$

MPO-deficient neutrophils are normally able to phagocytize most microbes. However, the ability of these cells to kill bacteria seems impaired. For organisms such as Staphylococcus aureus, Serratia species, and Escherichia coli, killing is initially impaired, but then reaches normal levels after a period of time. This suggests that an apparently slower, alternative mechanism of killing by these MPOdeficient cells is functioning. ${ }^{21}$

In contrast, the capacity to kill certain fungi seems completely absent in MPO-deficient neutrophils. In vitro studies have shown that Candida albicans, C. krusei, C. stellatoidea, and C. tropicalis cannot be killed by MPO-deficient polymorphonuclear leucocytes (PMNs). In contrast, an MPO-independent mechanism can kill C. glabrata, C. parapsilosis, and C. pseudotropicalis. This leads to the conclusion that bacterial killing may not necessarily be a problem for patients with MPO deficiency, but the killing of certain fungi may be difficult, depending on the severity of the deficiency. ${ }^{22-24}$ Despite this, there are few case reports of serious infectious complications associated with MPO deficiency. ${ }^{25-27}$

There is quite a bit of evidence suggesting that oxidative stress $^{28-32}$ and inflammation ${ }^{10-13}$ (particularly associated with the GI tract) are associated with autism. Studies have shown that MPO may serve as a biomarker for oxidative stress, ${ }^{33}$ and MPO deficiency may also be associated with an increase in incidence of inflammation. ${ }^{34}$

Interestingly, MPO may also play a role in the downregulation of the inflammatory response by regulating NK cells, decreasing peptide binding to chemotactic receptors, and auto-oxidizing and inactivating products of PMNs, such as alpha1-proteinase inhibitor and chemotaxins. ${ }^{2}$

MPO generates numerous reactive oxidants and diffusible radical species ${ }^{35}$ that are capable of both initiating lipid peroxidation ${ }^{36,37}$ and promoting an array of post-translational modifications to target proteins, including halogenation, nitration, and oxidative cross-linking. ${ }^{38,39}$ Lipid peroxidation 
Table 2 MPO concentration of autistic children with GI disease with ANCA (anti-MPO or anti-MPO/anti-PR3; bold) and withoutANCA are compared $(p=0.3718)$

\begin{tabular}{|c|c|c|c|c|}
\hline $\begin{array}{l}\text { Autistic with } \\
\text { GI Disease }\end{array}$ & $\begin{array}{l}\text { Mean O.D. } \\
\text { anti-PR3 }\end{array}$ & $\begin{array}{l}\text { Mean O.D } \\
\text { anti-MPO }\end{array}$ & $\begin{array}{l}\text { Mean MPO } \\
\text { ng/ml } \\
\text { No MPO ANCA }\end{array}$ & $\begin{array}{l}\text { Mean MPO } \\
\text { ng/ml } \\
\text { MPC ANCA }\end{array}$ \\
\hline \multicolumn{5}{|l|}{ Diagnosis } \\
\hline RA & 0.231 & 0.546 & & 0.00 \\
\hline A & 0.140 & $0.34 I$ & 2.10 & \\
\hline A & 0.214 & 0.620 & & 1.67 \\
\hline R-PDD & 0.245 & 0.416 & 1.51 & \\
\hline RA & 0.253 & 0.553 & & 1.44 \\
\hline RA & 0.366 & 0.450 & 2.47 & \\
\hline RA & 0.466 & 0.833 & & 2.13 \\
\hline RA & 0.134 & 0.274 & 0.86 & \\
\hline R-UD & 0.251 & 0.351 & 5.91 & \\
\hline RA & 0.147 & 0.302 & 1.94 & \\
\hline A & 0.129 & 0.322 & 1.45 & \\
\hline RA & 0.121 & 0.286 & 3.63 & \\
\hline PDD & 0.181 & 0.317 & 1.71 & \\
\hline A & 0.189 & $0.34 I$ & 4.19 & \\
\hline A & 0.401 & 0.630 & & 1.03 \\
\hline RA & 0.196 & 0.360 & 0.00 & \\
\hline A & 0.179 & 0.379 & 2.09 & \\
\hline RA & 0.175 & 0.329 & 2.87 & \\
\hline R-PDD & 0.443 & 0.539 & & 2.47 \\
\hline A & 0.576 & 0.629 & & 3.51 \\
\hline R-PDD & 0.278 & 0.529 & & 8.22 \\
\hline RA & 0.199 & 0.503 & & 4.98 \\
\hline RA & 0.544 & 0.504 & & 5.05 \\
\hline A & 0.218 & 0.387 & 3.94 & \\
\hline RA & 0.140 & 0.356 & 1.07 & \\
\hline RA & 0.259 & 0.463 & 2.58 & \\
\hline R-ASP & 0.099 & 0.225 & 1.08 & \\
\hline A & 0.174 & 0.457 & 2.97 & \\
\hline PDD & 0.197 & $0.36 \mathrm{I}$ & 2.34 & \\
\hline R-PDD & 0.274 & 0.506 & & 1.53 \\
\hline RA & 0.235 & 0.435 & 3.27 & \\
\hline A & 0.233 & 0.371 & 2.46 & \\
\hline RA & 0.482 & 0.566 & & 1.61 \\
\hline A & 0.136 & 0.284 & 3.22 & \\
\hline RA & 0.227 & 0.306 & 2.78 & \\
\hline RA & 0.221 & 0.537 & & 2.60 \\
\hline RA & 0.141 & 0.414 & 0.06 & \\
\hline A & 0.173 & 0.394 & 2.07 & \\
\hline RA & 0.166 & 0.313 & 2.02 & \\
\hline \multirow[t]{5}{*}{ RA } & 0.289 & 0.327 & 1.33 & \\
\hline & \multicolumn{2}{|c|}{ m } & 2.29 & 2.79 \\
\hline & \multicolumn{2}{|c|}{ sd } & 1.28 & 2.19 \\
\hline & \multicolumn{2}{|c|}{ sem } & 0.25 & 0.61 \\
\hline & \multicolumn{2}{|c|}{ ttest } & & \\
\hline
\end{tabular}

Abbreviations: ANCA, antineutrophil cytoplasmic antibodies; Gl, gastrointestinal; MPO, myeloperoxidase. 
Table 3 MPO concentration of autistic children with GI disease with (bold) and without LNH, with (bold) and without erythema and with (bold) and without severe total GI disease are compared

\begin{tabular}{|c|c|c|c|c|c|c|c|c|c|c|}
\hline \multicolumn{4}{|c|}{ Autistic With GI Disease } & \multirow{2}{*}{$\begin{array}{l}\text { MPO } \\
\frac{\mathrm{ng} / \mathrm{ml}}{\text { Total }}\end{array}$} & \multirow{2}{*}{$\begin{array}{l}\text { MPO } \\
\mathrm{ng} / \mathrm{ml} \\
\text { With LNH }\end{array}$} & \multirow{2}{*}{$\begin{array}{l}\text { MPO } \\
\text { ng/ml } \\
\text { With eryth }\end{array}$} & \multirow{2}{*}{$\begin{array}{l}\text { MPO } \\
\text { ng/ml } \\
\text { With total GI }\end{array}$} & \multirow[b]{3}{*}{ Group } & \multirow[b]{3}{*}{ MPO } & \multirow[b]{3}{*}{ LNH } \\
\hline Diagnosis & LNH & Eryth & Total GI & & & & & & & \\
\hline$\overline{R A}$ & 2 & 0 & 5 & 0.00 & & & & & & \\
\hline A & 3 & 0 & 6 & 2.10 & & & & Mean & 2.37 & 2.90 \\
\hline $\mathbf{A}$ & 3 & 6 & 9 & 1.67 & & 1.67 & 1.67 & SD & 1.62 & 1.63 \\
\hline R-PDD & I & 0 & 3 & 1.51 & & & & SEM & 0.28 & 0.67 \\
\hline RA & 1 & 0 & 3 & 1.44 & & & & $\mathrm{~N}$ & 34 & 6 \\
\hline RA & 2 & 2 & 6 & 2.47 & & & & $\mathrm{t}$ test & & \\
\hline RA & 4 & 3 & 8 & 2.13 & 2.13 & 2.13 & 2.13 & $P=0.4674$ & & \\
\hline RA & 2 & 0 & 8 & 0.86 & & & 0.86 & & & \\
\hline R-UD & 4 & 2 & 8 & 5.91 & 5.91 & & 5.91 & Group & MPO & Erythema \\
\hline RA & 3 & I & 7 & 1.94 & & & 1.94 & Mean & 2.48 & 2.26 \\
\hline A & 3 & I & 6 & 1.45 & & & & SD & 1.70 & 0.99 \\
\hline RA & I & 0 & 7 & 3.63 & & & 3.63 & SEM & 0.29 & 0.44 \\
\hline PDD & 2 & 2 & 6 & 1.71 & & & & $\mathrm{~N}$ & 35 & 5 \\
\hline A & 1 & 2 & 6 & 4.19 & & & & $\mathrm{t}$ test & & \\
\hline A & 3 & 5 & 10 & 1.03 & & 1.03 & 1.03 & $P=0.7806$ & & \\
\hline RA & 0 & 2 & 5 & 0.00 & & & & & & \\
\hline A & 2 & 1 & 5 & 2.09 & & & & Group & MPO & Total GI Disease \\
\hline RA & 3 & 1 & NA & 2.87 & & & & Mean & 2.07 & 3.13 \\
\hline R-PDD & 5 & 0 & NA & 2.47 & 2.47 & & & SD & 1.25 & 2.10 \\
\hline A & 4 & 4 & II & 3.51 & 3.51 & 3.51 & 3.51 & SEM & 0.26 & 0.56 \\
\hline R-PDD & 3 & I & 8 & 8.22 & & & 8.22 & $N$ & 24 & 14 \\
\hline RA & 3 & 2 & 5 & 4.98 & & & & $\mathrm{t}$ test & & \\
\hline RA & 3 & 0 & 7 & 5.05 & & & 5.05 & $\mathrm{P}=0.058$ & & \\
\hline A & 3 & 2 & 8 & 3.94 & & & 3.94 & & & \\
\hline RA & 2 & 0 & 4 & 1.07 & & & & & & \\
\hline RA & 3 & 0 & 4 & 2.58 & & & & & & \\
\hline R-ASP & 2 & I & 6 & 1.08 & & & & & & \\
\hline A & 3 & 4 & 6 & 2.97 & & 2.97 & & & & \\
\hline PDD & 2 & 1 & 4 & 2.34 & & & & & & \\
\hline R-PDD & 2 & I & 4 & 1.53 & & & & & & \\
\hline RA & 3 & 0 & 6 & 3.27 & & & & & & \\
\hline A & 2 & 0 & 4 & 2.46 & & & & & & \\
\hline RA & 3 & 2 & 6 & 1.61 & & & & & & \\
\hline A & 0 & 0 & NA & 3.22 & & & & & & \\
\hline RA & 3 & 0 & 5 & 2.78 & & & & & & \\
\hline RA & 2 & 2 & 7 & 2.60 & & & 2.6 & & & \\
\hline RA & 2 & 0 & 3 & 0.06 & & & & & & \\
\hline A & 4 & 0 & 7 & 2.07 & 2.07 & & & & & \\
\hline RA & 3 & 2 & 7 & 2.02 & & & 2.02 & & & \\
\hline \multirow[t]{3}{*}{ RA } & 6 & 0 & 10 & 1.33 & 1.33 & & 1.33 & & & \\
\hline & & $\mathrm{m}$ & & 2.45 & 2.90 & 2.26 & 3.13 & & & \\
\hline & & sd & & 1.62 & 1.63 & 0.99 & 2.10 & & & \\
\hline
\end{tabular}

Abbreviations: GI, gastrointestinal; LNH, lymphoid nodular hyperplasia; MPO, myeloperoxidase. 
has also been suggested to be a potential biomarker for autism. ${ }^{40-42}$

Some physicians, who have prescribed antifungals for autistic children with GI disease, have reported improvement in behaviors. We suggest that these improvements may be, at least in part, the result of MPO deficiency, which is acquired from antifungal administration and may result in reduced lipid peroxidation.

This report suggests that a subgroup of autistic children with GI disease have MPO deficiency. It is unclear whether this deficiency is acquired or inherited. Since MPO deficiency is associated with oxidative stress, increased inflammation, and propensity for fungal infections, all of which are mechanisms also associated with autism, one could hypothesize that MPO deficiency may be directly linked with GI pathology seen in this subgroup of autistic children.

Although we did not see a relationship between MPO levels in the autistic children with GI disease and severity of GI disease, or presence of ANCA, this could be explained by the fact that such a large number of individuals in this group had very low levels of MPO, making small differences insignificant.

One possible reason for this MPO deficiency in this subgroup is that children with GI disease, such as inflammatory bowel disease, as well as autistic children with GI disease, are often given anti-inflammatory drugs, which have been found to cause MPO deficiency. ${ }^{43-46}$ We did not have data available to investigate the possible relationship between antifungal therapy and MPO deficiency in this group of children with GI disease, but this area needs to be explored. If MPO deficiency is temporarily acquired because of antifungal therapy, and many autistic children receiving antifungal therapy are improving with respect to behavior, then is that improvement, at least in part, do to less oxidative stress and/or reduction in inflammation resulting from MPO reduction?

In summary, we have discovered that a group of autistic children with GI disease have MPO deficiency. Since the production of MPO is a major way that neutrophils are involved in antifungal defense, this deficiency may associate with increased fungal infection seen in many of these children. It is also possible, however, that anti-inflammatory and antifungal drugs given to this group of autistic children may be causing or exasperating the deficiency and that these very low levels of MPO result in reduced oxidative stress and improved behavior.

\section{Disclosures}

The authors report no conflicts of interest in this work.

\section{References}

1. Dale DC, Boxer L, Liles WC. The phagocytes: neutrophils and monocytes. Blood. 2008;112:935-945.

2. Nauseef WM. Insights into myeloperoxidase biosynthesis from its inherited deficiency. J Mol Med. 1998;76(10):661-668.

3. American Psychiatric Association. Diagnostic and Statistical Manual of Mental Disorders, 4th edition. Washington DC: American Psychiatric Association; 1994.

4. Gillberg C, Coleman M. The Biology of the Autistic Syndromes, 2nd edition. London, UK: Mac Keith Press; 1992.

5. Filipek $\mathrm{P}$, Accardo $\mathrm{P}$, Baranek G, et al. The screening and diagnosis of autistic spectrum disorders. J Autism Dev Disord. 1999;29(6):439-484.

6. Bailey A, Phillips W, Rutter M. Autism: towards an integration of clinical, genetic, neuro-psychological, and neurobiological perspectives. J Child Psychol Psychiatry 1996;37:89-126.

7. Horvath K, Perman J. Autistic disorder and gastrointestinal disease. Curr Opin Pediat. 2002;14:583-587.

8. Molloy C, Manning-Courtney P. Prevalence of chronic gastrointestinal symptoms in children with autism and autistic spectrum disorders. Autism. 2003;7:165-171.

9. Valicenti-McDermott M, McVicar K, Rapin I. Frequency of gastrointestinal symptoms in children with autistic spectrum disorders and association with family history of autoimmune disease. J Dev Behav Pediatr. 2006;27:(Suppl 2):S128-S136.

10. Ashwood P, Anthony A, Pellicer AA, Torrente F, Walker-Smith JA, Wakefield AJ. Intestinal lymphocyte populations in children with regressive autism: evidence for extensive mucosal immunopathology. J Clin Immunol. 2003;23(6):504-517.

11. Balzola F, Daniela C, Repici A, et al. Autistic enterocolitis: confirmation of a new inflammatory bowel disease in an Italian cohort of patients. Gastroenterology. 2005;128(Suppl 2):A-303.

12. Wakefield AJ, Puleston JM, Montgomery SM, Anthony A, O'Leary JJ, Murch SH. Review article: the concept of entero-colonic encephalopathy, autism and opioid receptor ligands. Aliment Pharmacol Ther. 2002;16:663-674.

13. Wakefield AJ, Anthony A, Murch SH, et al. Enterocolitis in children with developmental disorders. Am J Gastroenterol. 2000;95:2285-2295.

14. Shaw W, Kassen E, Chaves E. Increased urinary excretion of analogs of Krebs cycle metabolites and arabinose in two brothers with autistic features. Clin Chem. 1995;41:1094-1104.

15. Shaw W, Kassen E, Chaves E. Assessment of antifungal drug therapy in autism by measurement of suspected microbial metabolites in urine with gas chromatography-mass spectrometry. Clin Pract Alternat Med. 2000;1:15-26.

16. Russo AJ, Krigsman A, Jepson B, Wakefield A. Anti-PR3 and anti-MPO IgG ANCA in autistic children with chronic GI disease. Immunology and Immunogenetics Insights. 2009;2:21-28.

17. Russo AJ, Krigsman A, Jepson B, Wakefield A. Low serum alpha-1 antitrypsin associated with anti-PR-3 ANCA in autistic children with GI disease. Pediatrics and Genomics. 2009. In press.

18. Stefanescu A, Braun S, Ndrepepa G, et al. Prognostic value of plasma myeloperoxidase concentration in patients with stable coronary artery disease. Am Heart J. 2008;155:356-360.

19. Kutter D, Devaquet $P$, Vanderstocken $G$, et al. Consequences of total and subtotal myeloperoxidase deficiency: risk or benefit? Acta Haematol. 2000;104:10-15.

20. Cramer R, Soranzo MR, Dri P, et al. Incidence of myeloperoxidase deficiency in an area of northern Italy: histochemical, biochemical and functional studies. Br J Haematol. 1982;51:81-87.

21. Nauseef WM. Lessons from MPO deficiency about functionally important structural features. Jpn J Infect Dis. 2004;57(5):S4-S5.

22. Lanza F. Clinical manifestation of myeloperoxidase deficiency. $J$ Mol Med. 1998;76:676-681.

23. Parry MF, Root RK, Metcalf JA, Delaney KK, Kaplow LS, Richar WJ. Myeloperoxidase deficiency: prevalence and clinical significance. Ann Intern Med. 1981;95:293-301. 
24. Lehrer RI, Cline MJ. Leukocyte myeloperoxidase deficiency and disseminated candidiasis: the role of myeloperoxidase in resistance to Candida infection. J Clin Investig. 1969;48:1478-1488.

25. Kutter D. Prevalence of myeloperoxidase deficiency: population studies using Bayer-Technicon automated hematology. J Mol Med. 1998;76(10):669-675.

26. Nunoi H, Kohi F, Kajiwara H, Suzuki K. Prevalence of inherited myeloperoxidase deficiency in Japan. Microbiol Immunol. 2003; 47(7):527-531.

27. Taioli E, Benhamou S, Bouchardy C, et al. Myeloperoxidase G463A polymorphism and lung cancer: a HuGE genetic susceptibility to environmental carcinogens pooled analysis. Genet Med. 2007; 9:67-73.

28. Chauhan A, Chauhan V. Oxidative stress in autism. Pathophysiology. 2006;13(3):171-181.

29. Deth R, Muratore C, Benzecry J, Power-Charnitsky VA, Waly M. How environmental and genetic factors combine to cause autism: A redox/ methylation hypothesis. Neurotoxicology. 2008;29(1):190-201.

30. MacFabe DF, Rodríguez-Capote K, Hoffman JE, et al. The Kilee Patchell-Evans Autism Research Group. A novel rodent model of autism: intraventricular infusions of propionic acid increase locomotor activity and induce neuroinflammation and oxidative stress in discrete regions of adult rat brain. Am J Biochem Biotechnol. 2008;4(2): 146-166.

31. McGinnis WR. Could oxidative stress from psychosocial stress affect neurodevelopment in autism? J Autism Dev Disord. 2007;37(5): 993-994.

32. Yao Y, Walsh WJ, McGinnis WR, Praticò D. Altered vascular phenotype in autism: correlation with oxidative stress. Arch Neurol. 2006;63(8):1161-1164.

33. Honda H, Ueda M, Kojima S, et al. Assessment of myeloperoxidase and oxidative \{alpha\} 1-antitrypsin in patients on hemodialysis. Clin J Am Soc Nephrol. 2009;4(1):142-151.

34. Milla C, Yang S, Cornfield DN, et al. Myeloperoxidase deficiency enhances inflammation after allogeneic marrow transplantation. Am J Physiol Lung Cell Mol Physiol. 2004;287:L706-L714.
35. Klebanoff SJ. Oxygen metabolism and the toxic properties of phagocytes. Ann Intern Med. 1980;93:480-489.

36. Zhang R, Brennan ML, Shen Z, et al. Myeloperoxidase functions as a major enzymatic catalyst for initiation of lipid peroxidation at sites of inflammation. J Biol Chem. 2002;277:46116-46122.

37. Zhang R, Shen Z, Nauseef WM, Hazen SL. Defects in leukocytemediated initiation of lipid peroxidation in plasma as studied in myeloperoxidase-deficient subjects: systematic identification of multiple endogenous diffusible substrates for myeloperoxidase in plasma. Blood. 2002;99:1802-1810.

38. Podrez EA, Abu-Soud HM, Hazen SL. Myeloperoxidase-generated oxidants and atherosclerosis. Free Radic Biol Med. 2000;28: $1717-1725$.

39. Heinecke JW. Oxidative stress: new approaches to diagnosis and prognosis in atherosclerosis. Am J Cardiol. 2003;91:12A-16A.

40. Ming X, Stein TP, Brimacombe M, Johnson WG, Lambert GH, Wagner GC, Increased excretion of a lipid peroxidation biomarker in autism. Prostaglandins Leukot Essent Fatty Acids. 2005;73(5): 379-384.

41. Jory J, McGinnis W. Red-cell trace minerals in children with autism. American Journal of Biochemistry and Biotechnology. 2008;4:101-104.

42. Ming X, Chen M, Yochum C, Halliday A, Wagner G. Evidence of oxidative stress in autism derived from animal models. American Journal of Biochemistry and Biotechnology. 2008;4:218-225.

43. Ruzicka T, Bauer A, Glück S, Born M. Effects of dapsone on passive Arthus reaction and chemotaxis and phagocytosis of polymorphonuclear leukocytes. Arch Dermatol Res. 1981;270:347-351.

44. Stendahl O, Molin L, Dahigren C. The inhibition of polymorphonuclear leukocyte cytotoxicity by dapsone. A possible mechanism in the treatment of dermatitis herpetiformis. J Clin Invest. 1978;62:214-220.

45. Lanza F. Clinical manifestation of myeloperoxidase deficiency. $\mathrm{J} \mathrm{Mol}$ Med. 1998;76(10):676-681

46. Simmonds N, Millar A, Blake D, Rampton D. Antioxidant effects of aminosalicylates and potential new drugs for inflammatory bowel disease: assessment in cell-free systems and inflamed human colorectal biopsies. Aliment Pharmacol Ther. 1999;13:363-372.
Clinical and Experimental Gastroenterology

\section{Publish your work in this journal}

Clinical and Experimental Gastroenterology is an international, peerreviewed, open access journal, publishing all aspects of gastroenterology in the clinic and laboratory, including: Pathology, pathophysiology of gastrointestinal disease; Investigation and treatment of gastointestinal disease; Pharmacology of drugs used in the alimentary tract;

\section{Dovepress}

Immunology/genetics/genomics related to gastrointestinal disease This journal is indexed on CAS. The manuscript management system is completely online and includes a very quick and fair peer-review system. Visit http://www.dovepress.com/testimonials.php to read real quotes from published authors. 